\title{
Ant and termite diversity in Indonesian oil palm plantation: Investigating the effect of natural habitat existence
}

\author{
AKHMAD RIZALI ${ }^{1, \bullet}$, SRI KARINDAH ${ }^{1}$, ANNA WINDARI ${ }^{1}$, BAMBANG TRI RAHARDJO $^{1}$, NURINDAH $^{2}$, \\ BANDUNG SAHARI ${ }^{3}$ \\ ${ }^{1}$ Department of Plant Pests and Diseases, Faculty of Agriculture, Universitas Brawijaya. Jl. Veteran, Malang 65145, East Java, Indonesia. \\ Tel./fax.: +62-341-575843. `email: arizali@ub.ac.id \\ ${ }^{2}$ Indonesian Sweetener and Fiber Crops Research Institute. Jl. Raya Karangploso Km. 4, Malang 65152, East Java, Indonesia \\ ${ }^{3}$ PT. Astra Agro Lestari. Kawasan Industri Pulogadung, Blok OR 1-2, Jatinegara, Cakung, East Jakarta 13920, Jakarta, Indonesia
}

Manuscript received: 20 January 2019. Revision accepted: 6 March 2020.

\begin{abstract}
Rizali A, Karindah S, Windari A, Rahardjo BT, Nurindah, Sahari B. 2020. Ant and termite diversity in Indonesian oil palm plantation: Investigating the effect of natural habitat existence. Biodiversitas 21: 1326-1331. Natural habitat existence in oil palm plantation has high conservation value and plays an important role in maintaining biodiversity. However, different taxa may have different responses to the presence of natural habitats. This research was aimed to investigate the effect of natural habitat existence on ant and termite diversity in oil palm plantation. The field research was conducted in oil palm plantation located in Central Kalimantan, Indonesia. Twelve plots of oil palm plantation with different habitat characteristics were selected. Ants and termites were sampled using hand collection in six subplots for each plot. In total, 38 species of ants and 9 species of termites were collected from all rese arch areas. The results showed that the area of natural habitats and the distance of oil palm field to natural habitats affected the diversity of termites in the oil palm plantation, but ant diversity did not show to be affected by the same conditions. Based on the generalized linear model, the area of natural habitats in the oil palm plantation had a negative relationship with the diversity of termites. In conclusion, the termite species community is more affected by natural habitats than ants in oil palm plantation.
\end{abstract}

Keywords: Ant, area, Central Kalimantan, diversity, species richness, termite

\section{INTRODUCTION}

The existence of natural habitats around oil palm plantations has not been studied in terms of its role in supporting the conservation of insect diversity. Natural habitats can support much higher species diversity than oil palm plantation (Fitzherbert et al. 2008). In the landscape matrix of oil palm plantation, the remaining natural habitats are considered if they have high conservation value, especially the ability to maintain biodiversity (Azhar et al 2011). Research by Koh and Wilcove (2008) showed that $83 \%$ of butterfly species were only found in the natural habitats and not in the oil palm plantation. However, the role of natural habitats on social insects such as ants and termites in oil palm plantations still lacks understanding. Ants and termites occur in high abundances and with a high diversity of species in almost all natural ecosystems. Ant diversity can be very rich in species in natural ecosystems and agroecosystems (Alonso and Agosti 2000), while termite diversity is diverse and abundant in lowland forests (Bignell and Eggleton 2000).

Ants and termites play an important role in an agroecosystem. Ants provide important ecosystem services, including biological pest control, seed dispersal, and soil modification (Philpott et al. 2010), while termites are major agents of decomposition and play an important part in nutrient and carbon fluxes (Lawton et al. 1996). An experiment by Evans et al. (2011) showed that ants and termites can increase crop yields in an agroecosystem.
However, ants are sensitive to changes in their environment, including changes in dominant vegetation structure, food availability, and nesting resources (Andersen 2000). Meanwhile, several studies have shown that termites are sensitive to habitat disturbance (e.g. Eggleton et al. 2002; Sanabria et al. 2016; Schyra and Korb 2019). Wide-scale agricultural intensification and monoculture system in an oil palm plantation is presumed to be the primary factor that causes biodiversity decline and disturbs the ecological balance (Wood 1971; Vijay et al. 2016). Several studies revealed that monoculture oil palm plantation caused a decrease in arthropod biodiversity (e.g. Gazhali et al. 2016; Ashraf et al. 2018). As a consequence of biodiversity decline, ecological functions in an agroecosystem such as pollination and biological control are also suppressed (Feintrenie et al. 2010).

The diversity of ants and termites in agroecosystem can be affected by agricultural intensification. For example, in a coffee agroecosystem, the reduction in canopy complexity caused a decrease in ant species richness (Philpott et al. 2008). Human disturbance and land-use change are pivotal factors affecting ant (Gómez et al. 2003) and termite diversity (Jones et al. 2003). The communities of ants and termites are also highly sensitive to vegetation cover and agricultural practices (Sanabria et al. 2016). Nevertheless, the composition and richness of insect communities in transformed ecosystems may not be stable, even if management does not change (Kuussaari et al. 2009). Tropical agroecosystems established after forest 
conversion leads to a strong erosion over time of many forest species such as ants and termites (Luke et al. 2014). Understanding the value of natural habitats for insect conservation in an agroecosystem would be beneficial for developing a strategy to achieve sustainable agriculture. Yet, the conservation of natural habitats, as well as noncrop habitat in an agroecosystem, becomes the critical factor to increase habitat carrying capacity for supporting insects, for instance, the communities of natural enemies (Kruess and Tscharntke 1994).

The objective of this research was to investigate the effect of natural habitat existence on ant and termite diversity in oil palm plantation. Twelve oil palm fields in a plantation were selected by considering the two spatial scales of landscape-scale (distance and area of natural habitats) and field scale (tree age of oil palm and understorey vegetation diversity). The hypothesis tested in this research is that the presence of natural habitats maintains the community of ants and termites in an oil palm plantation.

\section{MATERIALS AND METHODS}

\section{Research location}

The research was conducted in an oil palm plantation located in Kotawaringin Barat District, Central Kalimantan, Indonesia. Four remaining natural habitats with different areas (536 ha, 62 ha, 18 ha, and 12 ha) within the plantation were designated. Twelve fields of oil palm were selected by considering their distance from those natural habitats. Also, the plots were classified as near $(<0.1 \mathrm{~km})$, medium $(1.5-2 \mathrm{~km})$ and far $(3-5 \mathrm{~km})$ with each distance group had four replications (Figure 1). The plots of oil palm had a size of $70 \mathrm{~m} \times 70 \mathrm{~m}$ and were selected by considering trees with a range of age between 11 to 18 years old, due to difficulty to found plantation with the same age.

\section{Sampling of ants and termites}

Sampling of ants and termites were conducted three times in different months from February to April 2017. In each plot, ants were collected from six subplots with a size of $5 \mathrm{~m} \mathrm{x} 5 \mathrm{~m}$ each. Ants sampling was performed by hand collection in each subplot lasted for a maximum of 30 minutes. While termites were observed in each plot within six transects with a size of $5 \mathrm{~m} \times 70 \mathrm{~m}$ each. Sampling of termites was also performed by hand collection in each transect lasted for a maximum of 30 minutes. Sampled of ants and termites were stored in small vials with $70 \%$ alcohol and given a label in the field before being sorted out and identified in the laboratory.

Specimens were identified using relevant taxonomic literature. Ants were identified to genera level based on Bolton (1994) and termites were based on Krishna et al. (2013). Both ants and termites were then separated into morphospecies level based on different morphological characteristics (Lattke 2000).

\section{Understorey vegetation observation}

In each plot, understorey vegetation diversity was observed. The observation was performed using the visual method by determining ten random points of a size of $1 \mathrm{~m}$ $\mathrm{x} 1 \mathrm{~m}$ in each plot. For each point, the diversity and density of vegetation were recorded, and each species was sampled and photographed for later identification in the laboratory. Sample and photograph of vegetation were identified using a reference of Xu and Zhou (2017).

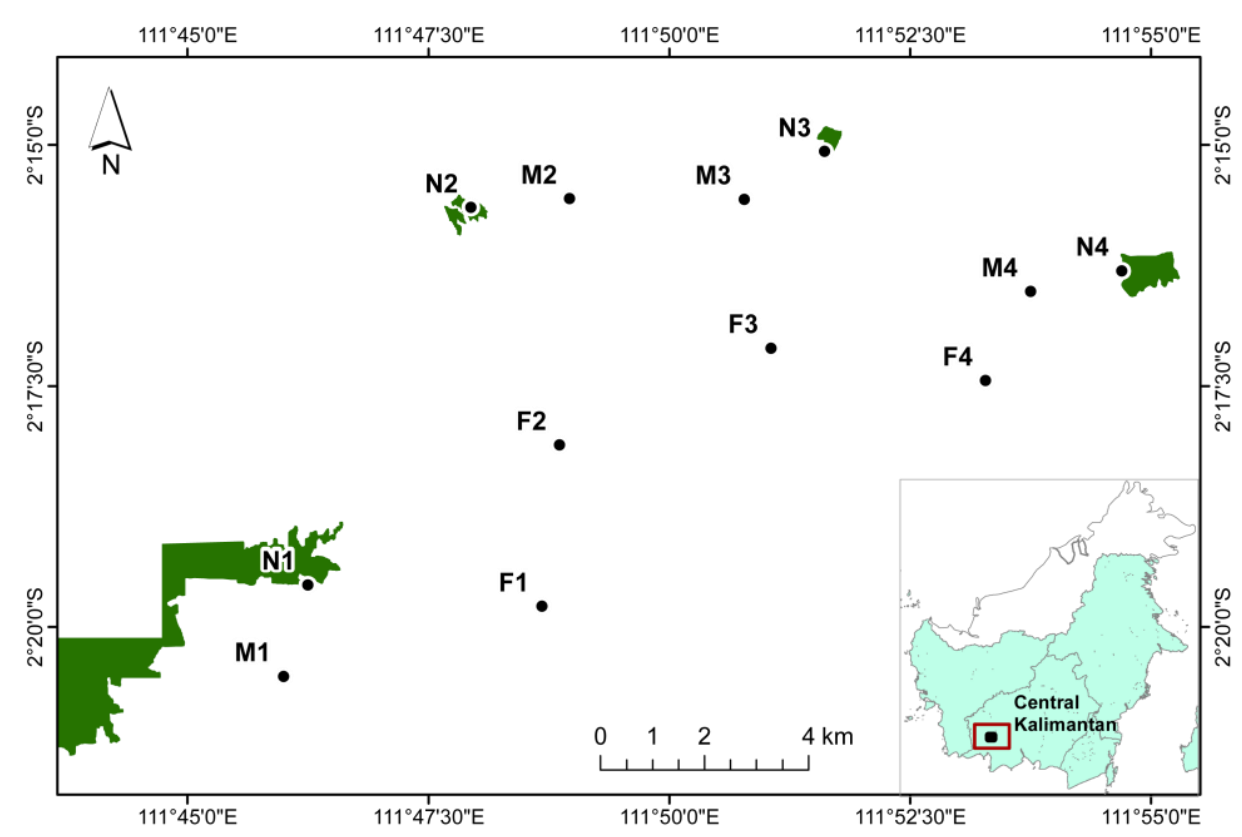

Figure 1. The research site, as an oil palm plantation located in Central Kalimantan, Indonesia (inset). The matrix is covered by the oil palm plantations and green colors indicate natural habitats. Dots with the letters indicate plot codes (N: near, M: medium, and F: far from natural habitat) and the numbers indicate replications 


\section{Data analysis}

The Kruskal-Wallis test was carried out to compare the significant difference of ant and termite diversity between different areas of natural habitats and between different distances to natural habitats. If significant differences were found, Fisher's least significant difference test was then used to compare the significant differences. The effect of natural habitats and other environmental factors on ant and termite diversity was analyzed by fitting a generalized linear model (GLM) without interactions (Zuur et al. 2009) and using a Gaussian distribution. Explanatory variables included termite/ant diversity, distance and area of natural habitats, tree age of oil palm, and diversity and density of understorey vegetation. All analyses were performed using R statistics (R Core Team 2019).

\section{RESULTS AND DISCUSSION}

\section{Diversity of ants and termites in oil palm plantations}

In total, 38 species of ants and 9 species of termites were collected from all research plots (Table 1). The result was similar to Luke et al. (2014) who found ants is also more diverse than termites in oil palm plantation in Sabah, Malaysia. The most common ant in oil plantation in Central Kalimantan was Pheidole sp2 (83\% of the total subplots), while the most common termite was Macrotermes sp (15\% of the total transects) (Table 2, Figure 2). In this research, we found invasive ant species, Anoplolepis gracilipes that known to cause a negative impact on insect biodiversity, although the occurrence (14\% of the total subplots) is lower than Pheidole sp2 (Table 2). A study by Brühl and Eltz (2009) also reported non-forest species including $A$. gracilipes as the most common ant species in an oil palm plantation in Sabah.

The presence of termites and ants has an important role in oil palm plantations. Termites may contribute to the decomposition of organic matter (Lawton et al. 1996), while ants play an important role as biological pest control (Philpott et al. 2010). The common termite species, Macrotermes sp. is known to feed on grass, dead wood, and leaf litter, with the help of fungal symbionts grown inside the nest (Luke et al. 2014). Research by Foster et al. (2011) reported that Macrotermes gilvus is the only species as the majority of decomposers in oil palm plantations. While the common ant species, Pheidole sp is recognized as widespread species that can dominate resources (Andersen 2000). However, the presence of A. gracilipes in oil palm plantations, besides cause negative impact on other ants also may suppress herbivores (Blüthgen and Feldhaar 2010).
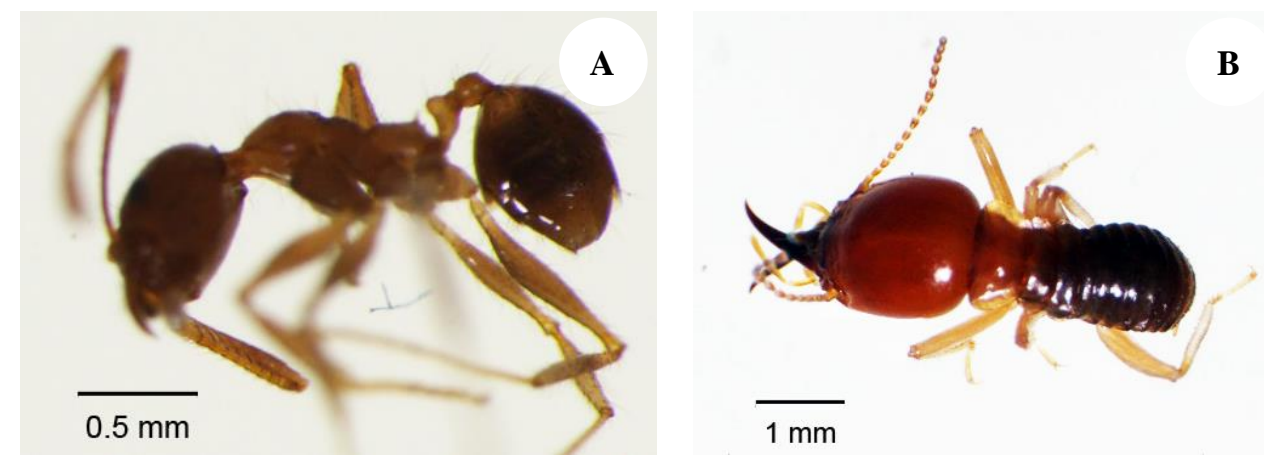

Figure 2. The most common species of ant (A) Pheidole sp2 and termite (B) Macrotermes sp.

Table 1. Ant and termite diversity and plot characteristics in oil palm plantation in Central Kalimantan. The letters of plot codes indicate different distance of oil palm field to natural habitat (N: near, M: medium, and F: far) and the numbers indicate replications

\begin{tabular}{|c|c|c|c|c|c|c|}
\hline \multicolumn{5}{|c|}{ Plot characteristics } & \multicolumn{2}{|c|}{ Species diversity } \\
\hline \multirow{2}{*}{ Code } & \multicolumn{2}{|c|}{ Distance to natural habitat } & \multirow{2}{*}{$\begin{array}{c}\text { Area of natural habitat } \\
\text { (ha) }\end{array}$} & \multirow{2}{*}{$\begin{array}{l}\text { Tree age } \\
\text { (years) }\end{array}$} & \multirow{2}{*}{ Ant } & \multirow{2}{*}{ Termite } \\
\hline & Group & Distance (m) & & & & \\
\hline N1 & Near & 96 & 536 & 14 & 16 & 1 \\
\hline N2 & Near & 86 & 18 & 12 & 13 & 3 \\
\hline $\mathrm{N} 3$ & Near & 77 & 12 & 11 & 7 & 0 \\
\hline N4 & Near & 60 & 62 & 17 & 22 & 1 \\
\hline M1 & Medium & 1,775 & 536 & 17 & 8 & 2 \\
\hline M2 & Medium & 1,640 & 18 & 17 & 12 & 1 \\
\hline M3 & Medium & 1,813 & 12 & 16 & 17 & 4 \\
\hline M4 & Medium & 1,770 & 62 & 18 & 13 & 4 \\
\hline $\mathrm{F} 1$ & Far & 4,183 & 536 & 16 & 17 & 1 \\
\hline $\mathrm{F} 2$ & Far & 4,500 & 18 & 14 & 13 & 1 \\
\hline F3 & Far & 3,928 & 12 & 16 & 10 & 3 \\
\hline \multirow[t]{2}{*}{$\mathrm{F} 4$} & Far & 3,223 & 62 & 17 & 13 & 3 \\
\hline & & & & Total & 38 & 9 \\
\hline
\end{tabular}


Table 2. Species list of ants and termites recorded from all studied plots in oil palm plantation in Central Kalimantan. Data is shown in the occurrence of subplots/transects (Occ.) and the percentage from total subplots/transect $(n=72)$ in the parentheses.

\begin{tabular}{|c|c|c|c|c|c|}
\hline \multicolumn{4}{|c|}{ Ant species } & \multicolumn{2}{|c|}{ Termite species } \\
\hline Species & Occ. $(\%)$ & Species & Occ. $(\%)$ & Species & Occ. $(\%)$ \\
\hline Anochetus sp1 & $4(6)$ & Odontoponera sp1 & $30(42)$ & Macrotermes sp & $11(15)$ \\
\hline Anochetus sp2 & $1(1)$ & Odontoponera sp2 & $2(3)$ & Microtermes sp1 & $5(7)$ \\
\hline Anoplolepis gracilipes & $10(14)$ & Oecophylla smaragdina & $10(14)$ & Microtermes sp2 & $2(3)$ \\
\hline Aphaenogaster sp1 & $15(21)$ & Pheidole sp2 & $60(83)$ & Odontotermes sp1 & $3(4)$ \\
\hline Camponotus sp1 & $14(19)$ & Pheidole sp3 & $18(25)$ & Odontotermes sp2 & $1(1)$ \\
\hline Cardiocandyla sp1 & $1(1)$ & Pheidole sp4 & $2(3)$ & Pericapritermes $\mathrm{sp}$ & $1(1)$ \\
\hline Crematogaster sp1 & $5(7)$ & Pheidole sp6 & $21(29)$ & Schedorhinotermes sp1 & $9(13)$ \\
\hline Crematogaster $\mathrm{sp} 2$ & $2(3)$ & Polyrhachis abdominalis & $4(6)$ & Schedorhinotermes sp2 & $2(3)$ \\
\hline Crematogaster sp3 & $4(6)$ & Polyrhachis sp2 & $1(1)$ & Termes sp & $7(10)$ \\
\hline Dorylus sp1 & $3(4)$ & Polyrhachis sp3 & $6(8)$ & & \\
\hline Dorylus sp2 & $3(4)$ & Polyrhachis sp4 & $1(1)$ & & \\
\hline Gnamptogenys sp & $11(15)$ & Polyrhachis sp10 & $2(3)$ & & \\
\hline Hyроропеra sp1 & $3(4)$ & Pristomyrmex sp1 & $17(24)$ & & \\
\hline Hypoponera $\mathrm{sp} 2$ & $4(6)$ & Solenopsis sp2 & $1(1)$ & & \\
\hline Meranoplus sp1 & $8(11)$ & Solenopsis sp4 & $1(1)$ & & \\
\hline Meranoplus sp2 & $8(11)$ & Strumigenys sp1 & $1(1)$ & & \\
\hline Myrmicinae sp & $1(1)$ & Technomyrmex sp2 & $8(11)$ & & \\
\hline Nylanderia sp1 & $25(35)$ & Tetramorium sp1 & $11(15)$ & & \\
\hline Nylanderia sp2 & $9(13)$ & Tetramorium $\mathrm{sp} 2$ & $11(15)$ & & \\
\hline
\end{tabular}

Based on the analysis, the area of natural habitats and the distance of oil palm field to natural habitats affected the termite diversity in oil palm plantation and did not affect the ant diversity. Ant diversity showed no difference between area of natural habitats $\left(\chi^{2}=1.211, \mathrm{P}=0.750\right)$ and distance from natural habitats $\left(\chi^{2}=2.392, \mathrm{P}=0.302\right)$ (Figure 3.A and 3.B). In contrast, termite diversity showed a significant difference between area of natural habitats $\left(\chi^{2}\right.$ $=12.858, \mathrm{P}=0.005)$ and distance from natural habitats $\left(\chi^{2}\right.$ $=9.244, \mathrm{P}=0.010)$. Termite diversity showed lower in oil palm plantations located around a wide area (536 ha) of natural habitats and near $(<0.1 \mathrm{~km})$ from natural habitats (Figure 3.C and 3.D).

Termite diversity showed different than ant diversity in relation to the presence of natural habitats within oil palm plantations. As the species with the greatest richness in a natural ecosystem as well as in an agroecosystem (Alonso and Agosti 2000), ants are also found diverse in an oil palm plantation in Central Kalimantan with different distances from natural habitats. Although ants are sensitive to changes in their environment (Andersen 2000), this research indicated that the spatial difference of oil palm fields around natural habitat did not affect the diversity of ants. Research by Cerda et al. (2009) in homogenous orchards also showed the same pattern that ant diversity was not different among different parts of orchards. This is arguably due to homogenous habitats tend to have similar food resources (Vandermeer et al. 2008) as well as temperature conditions (Wiescher et al. 2011) that shaping the similarity of ant community among oil palm fields. In contrast, termites as the most abundant species in lowland forests (Bignell and Eggleton 2000), their species diversity significantly affected by the spatial difference of oil palm fields. This is possibly related to the small scale effect within oil palm plantations that create a variety of understorey vegetation (Davies et al. 2003) as well as microhabitats for different termite species (Deblauwe et al. 2007).
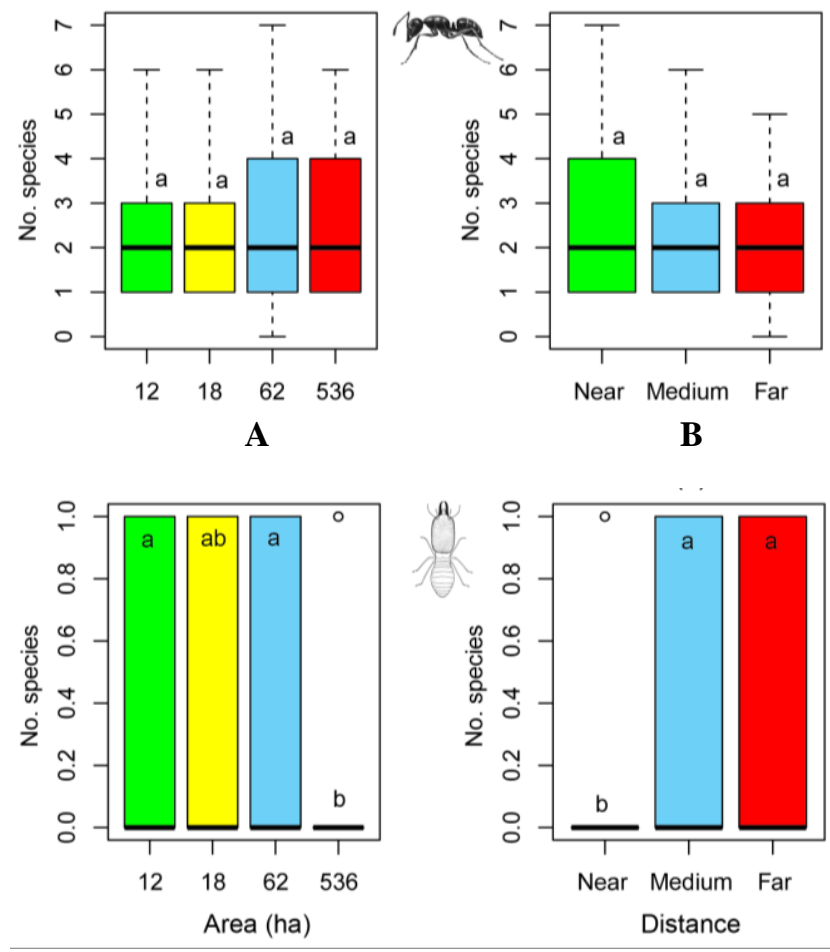

C

D

Figure 3. Differences in ant diversity between (A) area of natural habitats (ha) and (B) distance from natural habitats, and termite diversity between (C) area of natural habitats (ha) and (D) distance from natural habitats. Box plot represents the 1st and 3rd quartiles (the lower and upper edges of the box) as well as the median number of species (thick horizontal line in the box). Box with different letters are significantly different at $\mathrm{P}<0.05$ according to Fisher's least significant difference test 
Table 3. Generalized linear models relating diversity of ants and termites to distance from natural habitats, natural habitat area, tree age of oil palm plantations, and diversity and density of understorey vegetation as predictors

\begin{tabular}{lcccccc}
\hline \multirow{2}{*}{ Variable } & \multicolumn{3}{c}{ Ant diversity } & \multicolumn{3}{c}{ Termite diversity } \\
\cline { 2 - 6 } & Estimate & SE & P-value & Estimate & SE & P-value \\
\hline (Intercept) & 2.645 & 1.21 & 0.030 & 0.218 & 0.39 & 0.576 \\
Termite diversity & 0.167 & 0.22 & 0.445 & & & \\
Ant diversity & & & & 0.017 & 0.02 & 0.445 \\
Natural habitat distance & -0.000 & 0.00 & 0.301 & 0.000 & 0.00 & 0.086 \\
Area of natural habitat & 0.000 & 0.00 & 0.658 & -0.000 & 0.00 & 0.018 \\
Tree age of oil palm & 0.001 & 0.05 & 0.991 & 0.029 & 0.02 & 0.089 \\
Vegetation diversity & -0.027 & 0.05 & 0.567 & -0.028 & 0.01 & 0.054 \\
Vegetation density & 0.000 & 0.00 & 0.523 & 0.000 & 0.00 & 0.389 \\
\hline
\end{tabular}

\section{Effect of habitat characteristics on ants and termites}

The GLMs analyses showed the existence of natural habitats within oil palm plantation did not affect the diversity of ants $(\mathrm{P}>0.05)$ but effected the diversity of termites, especially the area of natural habitat $(\mathrm{P}=0.018$, Table 3). The area of natural habitat had a negative relationship with termite diversity. Oil palm fields that located around wide area of natural habitat may unsuitable for termite diversity due to the compatibility of natural habitat to support natural enemies of termites especially birds and mammals (Logan et al. 1990) in relation to the sufficiency in amount or composition to the predator existence (Tscharntke et al. 2016). Although ants are also as potential predator of termites (Logan et al. 1990; Grace 1997), there was no relationship between ant diversity and termite diversity $(\mathrm{P}=0.445$, Table 3$)$. This is because the majority of ant species in this research (Table 2) are not recognized as termite predators (Logan et al. 1990). A study in Amazonian rain forest by Dambros et al. (2016) also revealed that termite diversity was not correlated with non-predatory ant diversity.

The factors that cause the negative relationship between the area of natural habitats and termite diversity are still unclear. Some possibilities might shape the relationship such as the difference of habitat preference among termite species and the effect of termite predators. Specialist and generalist termites have different habitat preferences which specialist termites more prefer in natural habitats than in oil palm plantation (Logan et al. 1990). Also, the area of natural habitats may support termite predators (e.g. insectivorous birds and ants) that can affect the diversity of termites. Research by Heath and Long (2019) revealed that the predation of insectivorous birds increased with an increasing area of semi-natural habitat in orchards. This is related to the needs of insectivorous birds to consume a lot of insects (Nyffeler et al. 2018). Even specialized predators of the hive termites, doryline ants can cause termite extinction in the disturbance environments (Logan et al. 1990).

In conclusion, this study has identified significant differences in the diversity of ants and termites in responding to the existence of natural habitat in oil palm plantation. Although the mechanism is uncertain, the area of natural habitat in oil palm plantation had a negative relationship with termite diversity. It indicates that the termite species community appears more sensitive to the existence of natural habitats than ants.

\section{ACKNOWLEDGMENTS}

This research was funded by the Indonesian Oil Palm Estate Fund Agency (BPDPKS), the Ministry of Finance of the Republic of Indonesia. We thank PT Astra Agro Lestari, Tbk, for the permission to conduct field research in their oil palm plantation. We also thank Charis Taufan Nugroho, Radhian Ardy Prabowo, Ronny Pamuji, Ariatno, Sidik Purnomo, Santosa, and Agung Budianto, who provided support during the field research.

\section{REFERENCES}

Alonso LE, Agosti D. 2000. Biodiversity studies, monitoring and ants: an overview. In: Agosti D, Majer JD, Alonso LE, Schultz TR (eds) Ants: Standard Methods for Measuring and Monitoring Biodiversity. Smithsonian Institution Press, Washington.

Andersen AN. 2000. Global ecology of rainforest ants: functional groups in relation to environmental stress and disturbance. In: Agosti D, Majer JD, Alonso LE, Schultz TR (eds) Ants: Standard Methods for Measuring and Monitoring Biodiversity. Smithsonian Institution Press, Washington.

Ashraf M, Zulkifli R, Sanusi R, Tohiran KA, Terhem R, Moslim R, Norhisham AR, Ashton-Butt A, Azhar B. 2018. Alley-cropping system can boost arthropod biodiversity and ecosystem functions in oil palm plantations. Agric Ecosyst Environ 260: 19-26.

Azhar B, Lindenmayer DB, Wood J, Fischer J, Manning A, McElhinny C, Zakaria M. 2011. The conservation value of oil palm plantation estates, smallholdings and logged peat swamp forest for birds. For Ecol Manag 262: 2306-2315.

Bignell DE, Eggleton P. 2000. Termites in ecosystems. In: Abe T, Bignell DE, Higashi M (eds) Termites: Evolution, Sociality, Symbiosis, Ecology. Kluwer Academic Publications, Dordrecht, the Netherlands.

Blüthgen N, Feldhaar H. 2010. Food and shelter: how resources influence ant ecology. In: Lach L, Parr CL, Abbott KL (eds) Ant Ecology. Oxford University Press, New York.

Bolton B. 1994. Identification Guide to the Ant Genera of the World, Harvard University Press, Cambridge. 
Brühl CA, Eltz T. 2009. Fuelling the biodiversity crisis: species loss of ground-dwelling forest ants in oil palm plantations in Sabah, Malaysia (Borneo). Biodivers Conserv 19: 519-529.

Cerda X, Palacios R, Retana J. 2009. Ant community structure in citrus orchards in the Mediterranean Basin: impoverishment as a consequence of habitat homogeneity. Environ Entomol 38: 317-324.

Dambros CS, Morais JW, Vasconcellos A, Souza JLP, Franklin E, Gotelli NJ. 2016. Association of ant predators and edaphic conditions with termite diversity in an Amazonian rain forest. Biotropica 48: 237-245.

Davies RG, Hernández LM, Eggleton P, Didham RK, Fagan LL, Winchester NN. 2003. Environmental and spatial influences upon species composition of a termite assemblage across neotropical forest islands. J Trop Ecol 19: 509-524.

Deblauwe I, Dibog L, Missoup AD, Dupain J, Elsacker LV, Dekoninck W, Bonte D, Hendrickx F. 2007. Spatial scales affecting termite diversity in tropical lowland rainforest: a case study in southeast Cameroon. Afr J Ecol 46: 5-18.

Eggleton P, Bignell DE, Hauser S, Dibog L, Norgrove L, Madong B. 2002. Termite diversity across an anthropogenic gradient in the humid forest zone of West Africa. Agric Ecosyst Environ 90: 189-202.

Evans TA, Dawes TZ, Ward PR, Lo N. 2011. Ants and termites increase crop yield in a dry climate. Nature Communications $2: 7 \mathrm{pp}$.

Feintrenie L, Schwarze S, Levang P. 2010. Are local people conservationists? Analysis of transition dynamics from agroforests to monoculture plantations in Indonesia. Ecol Soc 15: 37.

Fitzherbert EB, Struebig MJ, Morel A, Danielsen F, Brühl CA, Donald PF, Phalan B. 2008. How will oil palm expansion affect biodiversity? Trends Ecol Evolut 23: 538-545.

Foster WA, Snaddon JL, Turner EC, Fayle TM, Cockerill TD, Ellwood MDF, Broad GR, Chung AYC, Eggleton P, Khen CV, Yusah KM 2011. Establishing the evidence base for maintaining biodiversity and ecosystem function in the oil palm landscapes of South East Asia. Philos Trans R Soc Lond B Biol Sci 366: 3277-3291.

Gazhali A, Asmah S, Syafiq M, Yahya MS, Aziz N, Peng T, Norhisham AR, Puan CL, Turner EC, Azhar B. 2016. Effects of monoculture and polyculture farming in oil palm smallholdings on terrestrial arthropod diversity. J Asia-Pac Entomol 19: 415-421.

Gómez C, Casellas D, Oliveras J, Bas JM. 2003. Structure of groundforaging ant assemblages in relation to land-use change in the northwestern Mediterranean region. Biodivers Conserv 12: 2135 2146.

Grace JK. 1997. Biological control strategies for suppression of termites. J Agric Entomol 14: 281-289.

Heath SK, Long RF. 2019. Multiscale habitat mediates pest reduction by birds in an intensive agricultural region. Ecosphere 10: e02884.

Jones DT, Susilo FX, Bignell DE, Hardiwinoto S, Gillison AN, Eggleton P. 2003. Termite assemblage collapse along a land-use intensification gradient in lowland central Sumatra, Indonesia. J Appl Ecol 40: 380391

Koh LP, Wilcove DS. 2008. Is oil palm agriculture really destroying tropical biodiversity? Conserv Lett 1: 60-64.

Krishna K, Grimaldi DA, Krishna V, Engel MS. 2013. Treatise on the Isoptera of the world. Bull Ame Mus Nat Hist 377: 1-2704.

Kruess A, Tscharntke T. 1994. Habitat fragmentation, species loss, and biological control. Science 264: 1581-1584.

Kuussaari M, Bommarco R, Heikkinen RK, Helm A, Krauss J, Lindborg R, Ockinger E, Partel M, Pino J, Roda F, Stefanescu C, Teder T,
Zobel M, Steffan-Dewenter I. 2009. Extinction debt: a challenge for biodiversity conservation. Trends Ecol Evol 24: 564-571.

Lattke JE. 2000. Specimen processing: building and curating an an collection. In: Agosti D, Majer JD, Alonso LE, Schultz TR (eds) Ants: Standard Methods for Measuring and Monitoring Biodiversity. Smithsonian Institution Press, Washington.

Lawton JH, Bignell DE, Bloemers GF, Eggleton P, Hodda ME. 1996. Carbon flux and diversity of nematodes and termites in Cameroon forest soils. Biodivers Conserv 5: 261-273.

Logan JWM, Cowie RH, Wood TG. 1990. Termite (Isoptera) control in agriculture and forestry by non-chemical methods: a review. Bull Entomol Res 80: 309-330.

Luke SH, Fayle TM, Eggleton P, Turner EC, Davies RG. 2014. Functional structure of ant and termite assemblages in old growth forest, logged forest and oil palm plantation in Malaysian Borneo. Biodivers Conserv 23: 2817-2832.

Nyffeler M, Sekercioglu CH, Whelan CJ. 2018. Insectivorous birds consume an estimated 400-500 million tons of prey annually. Naturwissenschaften 105: 47.

Philpott SM, Perfecto I, Armbrecht I, Parr CL. 2010. Ant diversity and function in disturbed and changing habitats. In: Lach L, Parr CL, Abbott KL (eds) Ant Ecology. Oxford University Press, New York.

Philpott SM, Arendt WJ, Armbrecht I, Bichier P, Diestch TV, Gordon C, Greenberg R, Perfecto I, Reynoso-Santos R, Soto-Pinto L, TejedaCruz C, Williams-Linera G, Valenzuela J, Zolotoff JM. 2008. Biodiversity loss in Latin American coffee landscapes: review of the evidence on ants, birds, and trees. Conserv Biol 22: 1093-1105.

R Core Team. 2019. R: A Language and Environment for Statistical Computing. R Foundation for Statistical Computing, Vienna, Austria.

Sanabria C, Dubs F, Lavelle P, Fonte SJ, Barot S. 2016. Influence of regions, land uses and soil properties on termite and ant communities in agricultural landscapes of the Colombian Llanos. Europ J Soil Biol 74: 81-92.

Schyra J, Korb J. 2019. Termite communities along a disturbance gradient in a West African savanna. Insects 10 .

Tscharntke T, Karp DS, Chaplin-Kramer R, Batáry P, DeClerck F, Gratton C, Hunt L, Ives A, Jonsson M, Larsen A, Martin EA, Martínez-Salinas A, Meehan TD, O'Rourke M, Poveda K, Rosenheim JA, Rusch A, Schellhorn N, Wanger TC, Wratten S, Zhang W. 2016. When natural habitat fails to enhance biological pest control - Five hypotheses. Biol Conserv 204: 449-458.

Vandermeer J, Perfecto I, Philpott SM. 2008. Clusters of ant colonies and robust criticality in a tropical agroecosystem. Nature 451: 457-9.

Vijay V, Pimm SL, Jenkins CN, Smith SJ. 2016. The Impacts of oil palm on recent deforestation and biodiversity loss. PLoS ONE 11: e0159668.

Wiescher PT, Pearce-Duvet JMC, Feener DH. 2011. Environmental context alters ecological trade-offs controlling ant coexistence in a spatially heterogeneous region. Ecol Entomol 36: 549-559.

Wood BJ. 1971. Development of integrated control programs for pests of tropical perennial crops in Malaysia. In: Huffaker CB (ed) Biological Control. Plenum Press, New York.

$\mathrm{Xu} \mathrm{Z}$, Zhou G. 2017. Identification and Control of Common Weeds: Volume 1-3, Springer, Dordrecht.

Zuur AF, Ieno EN, Walker NJ, Saveliev AA, Smith GM. 2009. Mixed Effects Models and Extensions in Ecology with R. Springer, New York 